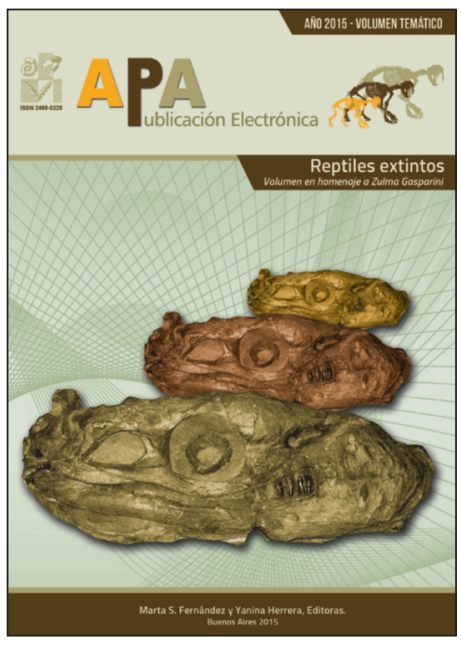

\title{
METRIORHYNCHIDAE (CROCODYLOMORPHA: THALATTOSUCHIA) FROM UPPER JURASSIC-LOWER CRETACEOUS OF NEUQUÉN BASIN (ARGENTINA), WITH COMMENTS ON THE NATURAL CASTS OF THE BRAIN
}

CONICET. División Paleontología Vertebrados, Museo de La Plata, Universidad Nacional de La Plata, Paseo del Bosque s/n, B1900FWA La Plata, Argentina.

Recibido: 9 de Junio de 2015 - Aceptado: 22 de Septiembre de 2015

Para citar este artículo: Yanina Herrera (2015). Metriorhynchidae (Crocodylomorpha: Thalattosuchia) from Upper Jurassic - Lower Cretaceous of Neuquén Basin (Argentina), with comments on the natural casts of the brain. En: M. Fernández y Y. Herrera (Eds.) Reptiles Extintos - Volumen en Homenaje a Zulma Gasparini. Publicación Electrónica de la Asociación Paleontológica Argentina 15(1): 159-171.

Link a este artículo: http://dx.doi.org/10.5710/PEAPA.09.06.2015.104

DESPLAZARSE HACIA ABAJO PARA ACCEDER AL ARTÍCULO

Asociación Paleontológica Argentina Maipú $6451^{\circ}$ piso, C1006ACG, Buenos Aires República Argentina

Tel/Fax (54-11) 4326-7563 Web: www.apaleontologica.org.ar

Otros artículos en Publicación Electrónica de la APA 15(1):

\section{de la Fuente \& Sterli}

ESTADO DEL CONOCIMIENTO DE LAS TORTUGAS EXTINTAS DEL TERRITORIO ARGENTINO: UNA PERSPECTIVA HISTÓRICA.

\section{Paulina Carabajal}

GUIA PARA EL ESTUDIO DE LA NEUROANATOMÍA DE DINOSAURIOS SAURISCHIA, CON ENFASIS EN FORMAS SUDAMERICANAS.

\section{Pol \& Leardi}

DIVERSITY PATTERNS OF NOTOSUCHIA (CROCODYLIFORMES, MESOEUCROCODYLIA) DURING THE CRETACEOUS OF GONDWANA. 


\title{
METRIORHYNCHIDAE (CROCODYLOMORPHA: THALATTOSUCHIA) FROM UPPER JURASSIC-LOWER CRETACEOUS OF NEUQUÉN BASIN (ARGENTINA), WITH COMMENTS ON THE NATURAL CASTS OF THE BRAIN
}

\author{
YANINA HERRERA
}

CONICET. División Paleontología Vertebrados, Museo de La Plata, Universidad Nacional de La Plata, Paseo del Bosque s/n, B1900FWA La Plata, Argentina. yaninah@fcnym.unlp.edu.ar

\begin{abstract}
Metriorhynchidae was the only Crocodylomorpha with a pelagic marine lifestyle. Related to this lifestyle, its peculiar body plan allows clearly differentiate them from others Crocodylomorpha. The fossil record of metriorhynchids from Tithonian-Berriasian levels of the Vaca Muerta Formation (Neuquén Basin, Argentina) is outstanding, in terms of quantitative and qualitative record. Its taxonomical diversity is composed by four taxa: Cricosaurus araucanensis, Cricosaurus lithographicus, Dakosaurus andiniensis, and Purranisaurus potens. This fossil record is also characterized by the tridimensional preservation of the materials and by the preservation of numerous natural endocasts of the skull cavities. Here, I made a description of the natural endocasts of the brain of Cricosaurus araucanensis together with a synthesis of the advances in the knowledge of these four taxa that were performed during the last years. The information that provides the endocasts, together with the quantity of endocasts, make of the Patagonian fossil record of metriorhynchids a key to the exploration and reconstruction of soft anatomy of these crocodylomorphs, and for the understanding of the physiological changes that accompanied the structural changes of the skeleton. Understanding these changes will allow defining the key innovations that allowed to the metriorhynchids conquer the pelagic environment, unparalleled among archosaurs.
\end{abstract}

Key words. Cricosaurus. Dakosaurus. Purranisaurus. Tithonian. Berriasian. Vaca Muerta Formation. Paleobiological aspects.

Resumen. METRIORHYNCHIDAE (CROCODYLOMORPHA: THALATTOSUCHIA) DEL JURÁSICO SUPERIOR-CRETÁCICO INFERIOR DE LA CUENCA NEUQUINA (ARGENTINA), CON COMENTARIOS SOBRE LOS MOLDES NATURALES DEL ENCÉFALO. Los Metriorhynchidae fueron los únicos Crocodylomorpha con un estilo de vida marino pelágico. Relacionado con este estilo de vida, su peculiar plan corporal permite diferenciarlos claramente de los demás Crocodylomorpha. El registro fósil de los metriorrínquidos titonienses-berriasienses de la Formación Vaca Muerta (Cuenca Neuquina, Argentina) es excepcional, tanto en términos cuantitativos como cualitativos. Su diversidad taxonómica está compuesta por cuatro taxones: Cricosaurus araucanensis, Cricosaurus lithographicus, Dakosaurus andiniensis y Purranisaurus potens. Este registro fósil también se caracteriza por la preservación tridimensional de los materiales y por la preservación de numerosos moldes naturales de las cavidades del cráneo. En este trabajo se presenta una descripción de los moldes naturales del encéfalo de Cricosaurus araucanensis junto con una síntesis de los avances en el conocimiento realizados, en los últimos años, sobre estos cuatro taxones argentinos. La calidad de la información que aporta los moldes naturales, sumado a la cantidad de moldes recuperados, hacen del registro patagónico una pieza clave para la exploración y reconstrucción de la anatomía blanda de estos crocodilomorfos, y para la comprensión de los cambios fisiológicos que acompañaron los cambios estructurales del esqueleto. La comprensión de estos cambios permitirá delimitar las innovaciones evolutivas claves que le permitieron a los metriorrínquidos la conquista, sin paralelo entre los arcosaurios, del medio pelágico.

Palabras clave. Cricosaurus. Dakosaurus. Purranisaurus. Titoniense. Berriasiense. Formación Vaca Muerta. Aspectos paleobiológicos.

Throughout the Neuquén Basin (west-central Argentina), several localities have yielded abundant and well-preserved Mesozoic marine reptiles remains. They come from Early Jurassic to Early Cretaceous levels and constitute the most diverse marine herpetofauna from Gondwana. This remarkable assemblage is mainly conformed by ichthyo- saurs, pliosaurs, marine testudines, and metriorhynchids (Gasparini and Fernández, 2005, 2011).

Metriorhynchidae was a successful group of crocodylomorphs that differs from all other crocodylomorphs by: paddle-like forelimbs, hypocercal tail, osteoporotic-like bone tissue, loss of osteoderms (e.g., Fraas, 1902; Andrews, 
1913; Hua and Buffrénil, 1996; Young et al., 2010), and enlarged external carotid foramen and canal, enlarged and highly vascularised nasal salt gland, preorbital fenestra related with the drainage of salt gland, and reduced olfactory tract and bulbs (Fernández and Gasparini, 2000, 2008; Fernández and Herrera, 2009; Pol and Gasparini, 2009; Fernández et al., 2011; Herrera et al., 2013a; Herrera and Vennari, 2015). Metriorhynchidae is a Middle Jurassic to Early Cretaceous group that mainly lived in the Tethys and Pacific oceans. Regarding South America, the oldest record of metriorhynchids from Argentina comes from upper Bathonian (Middle Jurassic) of Los Molles Formation (Gasparini et al., 2005). However, the fossil record of metriorhynchids is particularly abundant, and well preserved, in TithonianBerriasian levels of the Vaca Muerta Formation.

The first detailed studies of metriorhynchids from Argentina (e.g., Gasparini, 1973a; Gasparini and Dellapé, 1976) were originated from the doctoral thesis performed by Dr. Zulma Brandoni de Gasparini (Gasparini, 1973b). Later, she also conducted a series of studies about Chilean (e.g., Gasparini and Chong Díaz, 1977; Gasparini et al., 2000) and Cuban (e.g., Gasparini and Iturralde-Vinent, 2001) metriorhynchids. For almost 30 years, her work was focused in the description of new taxa and the study of their paleobiogeographic relations with Tethys fauna (e.g., Gasparini and Dellapé, 1976; Gasparini and Chong Díaz, 1977; Vignaud and Gasparini, 1996; Gasparini et al., 2000). In the late 90 s, the finding of some natural casts of the nasal salt gland of Cricosaurus araucanensis in the collection of the División Paleontología Vertebrados (Museo de La Plata) was the base of a series of works in which paleobiological aspects of Patagonian metriorhynchid began to be analyzed. Fernández and Gasparini (2000, 2008), Fernández and Herrera (2009), and Herrera et al. (2013a) described the natural casts of the preorbital region (i.e., nasal gland, paranasal sinus system and related structures) of the skull.

The latest Patagonian metriorhynchids review was made by Pol and Gasparini (2007). Since that date a lot of progresses were made, mainly in some paleobiological aspects of the group. Here I review the advances in the knowledge of the group in Argentina for the four Late Jurassic-Early Cretaceous taxa found in several localities of the Vaca Muerta Formation (Neuquén Basin), which were previously studied by Zulma Gasparini. Additionally, and mostly based on the material found in the fieldtrips conduced in 20082011 in the Pampa Tril area (Vaca Muerta Formation), a description of the natural brain endocasts of Cricosaurus araucanensis is included.

Institutional abbreviations. MHNSR, Museo de Historia Natural de San Rafael, San Rafael, Mendoza, Argentina; MLP, Museo de La Plata, La Plata, Buenos Aires, Argentina; MJCM, Museo de Ciencias Naturales y Antro-pológicas "Juan Cornelio Moyano", Mendoza, Argentina; MOZ, Museo Provincial de Ciencias Naturales "Prof. Dr. Juan A. Olsacher", Zapala, Neuquén, Argentina.

\section{METRIORHYNCHIDS FROM VACA MUERTA FORMATION}

Based on the supra-generic taxonomy of Metriorhynchoidea updated by Young and Andrade (2009), Young et al. (2010, 2011), and Cau and Fanti (2011), the Late JurassicEarly Cretaceous Argentinean metriorhynchids are included in the Rhacheosaurini and Geosaurini tribes. Rhacheosaurini are mainly characterized by having gracile skulls with long and tubular snouts, and acute carinated teeth without true denticles in the carinae (e.g., Cricosaurus), whereas Geosaurini have strong skull, bicarinated, large and robust teeth with a row of true denticles along the carinae (e.g., Dakosaurus).

\section{SYSTEMATIC PALEONTOLOGY}

Superorder CROCODYLOMORPHA Walker, 1970

Infraorder ThalatTosuchia Fraas, 1901

Family MetrIORHYNCHIDAE Fitzinger, 1843 (sensu Young and Andrade, 2009)

Subfamily MetrioRhynCHINAE Fitzinger, 1843 (sensu Young and Andrade, 2009)

Tribe Rhacheosaurinı Young, Bell and Brusatte, 2011

Genus Cricosaurus Wagner, 1858

Type species. Steneosaurus [sic] elegans Wagner, 1852. Early Tithonian, Mörnsheim Formation, Germany.

Cricosaurus araucanensis (Gasparini and Dellapé, 1976)

Figures 1-2 
(1)

(3)

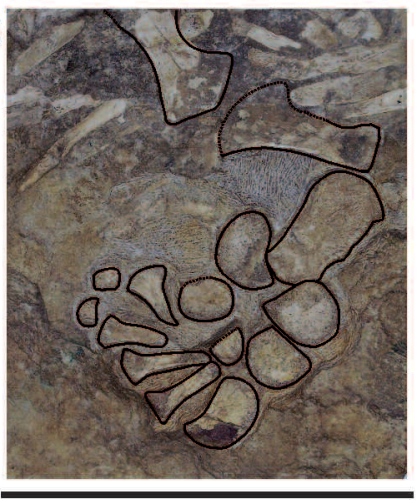

(2)

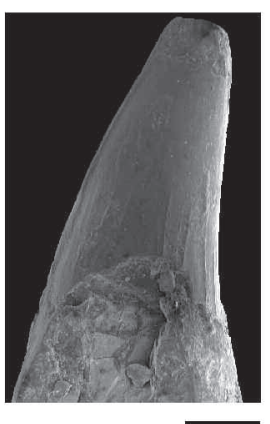

(4)

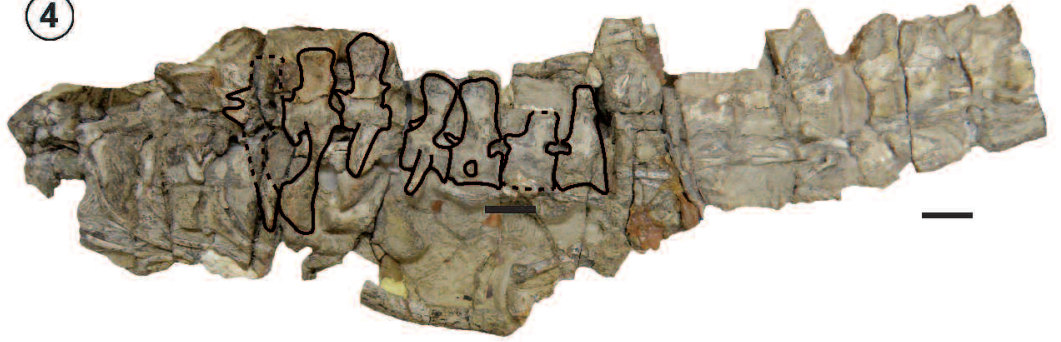

(5)

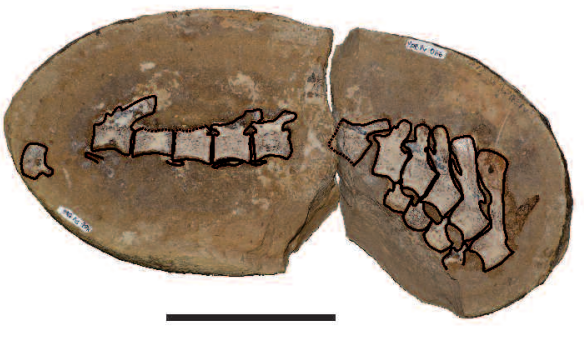

(8)

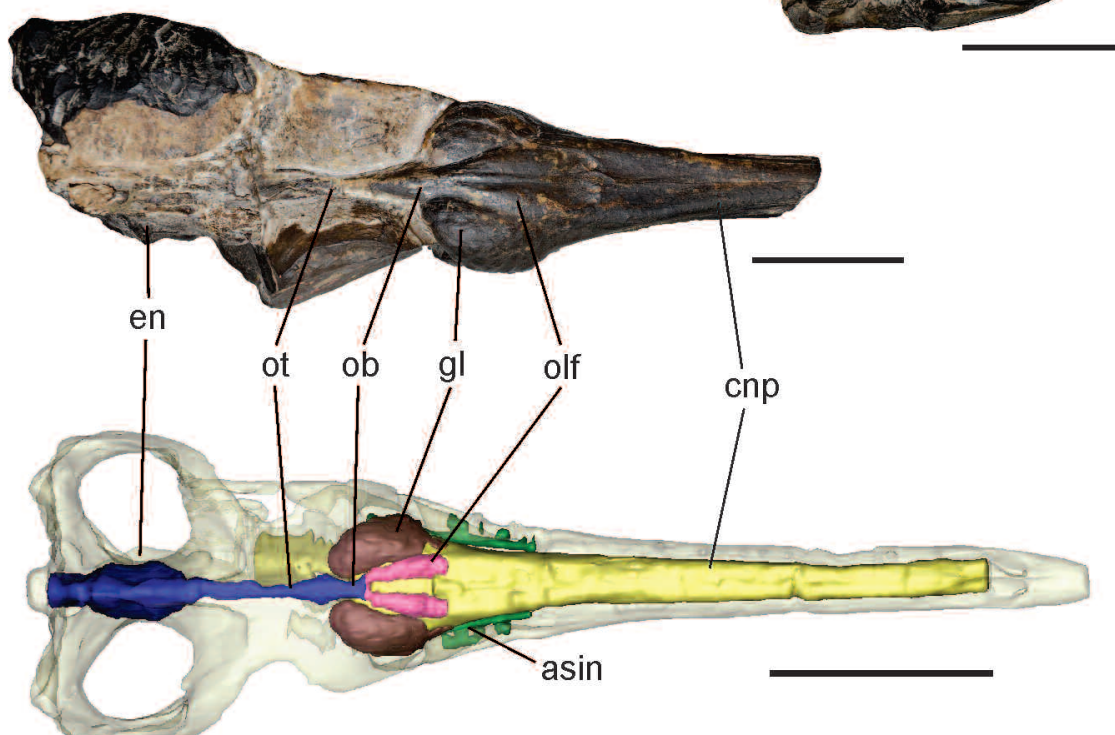

(9)
(6)

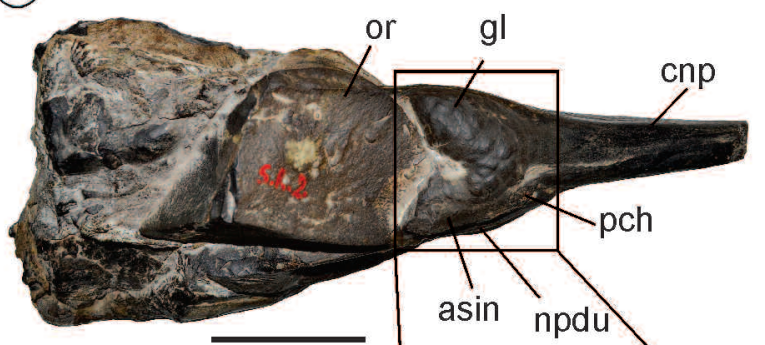

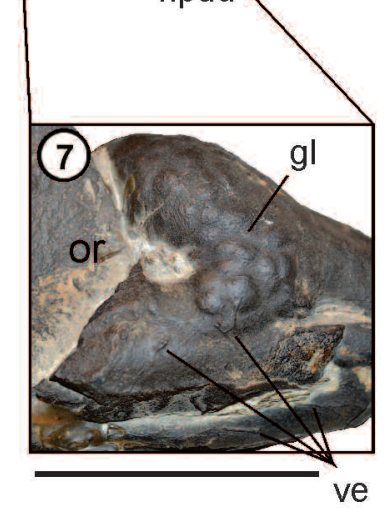

Figure 1. Cricosaurus araucanensis. 1, MLP 72-IV-7-1, skull in dorsal view; 2, MLP 72-IV-7-4, maxilar tooth in lingual view; 3, MLP 73-II-27-1, left forelimb in ventral view; 4, MLP 73-II-27-6, postcranial elements in left lateral view; 5, MOZ-PV 066, caudal vertebrae in left lateral view showing the tail bend region; 6, MLP 76-XI-19-1, natural endocast in right lateral view; 7, detail of nasal salt gland in ventrolateral view; 8 , MLP 76-XI-19-1, natural endocast in dorsal view; 9, MLP 72-IV-27-1 reconstructed skull, paranasal sinuses and other cephalic components in dorsal view. Scale bars= 1, 5, 9, 100 mm; 2, 1 mm; 3, 6-8, 50 mm; 4, 30 mm. Abbreviations: asin, antorbital sinus; cnp, nasal cavity proper; en, endocast of brain cavity; gl, exocrine gland; npdu, nasopharyngeal duct; ob, olfactory bulb; olf, olfactory region of the nasal cavity; or, orbit; ot, olfactory tract; pch, primary choana; ve, vessel. 
Holotype. MLP 72-IV-7-1, complete skull and mandible, and postcranial elements comprised by five postaxial cervical vertebrae, 16 dorsal vertebrae, two sacral and four caudal vertebrae, ribs, gastralia, haemal arches, incomplete pectoral girdle and forelimbs, and incomplete pelvic girdle and hind limbs.

Referred material. Specimens MPL 72-IV-7-2, MLP 72-IV7-3, MLP 72-IV-7-4, MLP 72-IV-7-10, MLP 73-II-27-1, MLP 73-II-27-6, MLP 86-XI-5-7, MLP 86-XI-10-6*, MLP 86-XI-10-7, MLP 92-III-6-1*, MOZ-PV 066 are represented by skeletal elements (partially preserved skulls and/or postcranial elements, in a few cases $\left[{ }^{*}\right]$ portions of natural endocasts are exposed), whereas the specimens MLP 73II-27-3, MLP 76-XI-19-1, MLP 84-V-1-1, MOZ-PV 7201, MOZ-PV 7202, MOZ-PV 7204, MOZ-PV 7207, and MOZ-PV 7261 are natural endocasts of the skull cavities.

Ocurrence. The holotype and the specimens MPL 72-IV-72, MLP 72-IV-7-3, MLP 72-IV-7-4, MLP 72-IV-7-10, MLP 86-XI-5-7, MLP 73-II-27-6, MLP 86-XI-10-6, and MLP 92III-6-1 were found in Cerro Lotena (Portada Covunco Member, middle Tithonian). Specimens MLP 73-II-27-1, MLP 73-II-27-2, MLP 73-II-27-4, MLP 73-II-27-5, and MLP 73II-27-3 came from Tithonian sediments of the Bosque Petrificado (about $7 \mathrm{~km}$ to southwest of Cerro Lotena). MLP 86-XI-10-7 was found in Cerro Granito (Tithonian). MOZ-PV 7202, MOZ-PV 7203, MOZ-PV 7204, MOZ-PV 7207 were found in Yesera del Tromen-Pampa Tril (Tithonian-Berriasian). All these sites are located in Neuquén Province. MLP 76-XI-19-1 and MLP 84-V-1-1 were found in Tithonian levels of Sierra de Reyes in Mendoza Province.

Comments. Gasparini and Dellapé (1976) nominated the species as Geosaurus araucanensis and described an excellent three-dimensional preserved skull. More than 30 years after its nomination Geosaurus araucanensis was re-assigned to Cricosaurus, based on the proposal of Young and Andrade (2009). Cricosaurus araucanensis is one of the most complete and best-known taxon of the cosmopolitan genus Cricosaurus. In its original description, the authors mentioned the postcranial elements preservation associated to the skull but they did not describe them. Worldwide, the postcranial elements of metriorhynchids in general are poorly documented in comparison with their skulls. The postcranial description of $C$. araucanensis revealed that the deeply modified forelimbs transformed as paddles and its poor ossification, together with the delayed timing of neurocentral closure, which was observed in caudal vertebrae, are related with the occurrence of skeletal paedomorphosis, a widespread heterochronic process among secondarily adapted aquatic reptiles (Herrera et al., 2009, 2013b; Herrera, 2012). The morphology of the caudal region with the transverse processes of the first caudal vertebrae ventrally deflected, and the reduction of the fourth trochanter, suggested a reduction of the hypaxial musculature allowing an increase in the epaxial musculature (Herrera et al., 2013b). Additionally, the shape and the reduced size of the pelvic girdle of metriorhynchids indicate a reduction in available space for hind limb's muscles and therefore a reduction of the musculature of the limb. This suggests that some movements of the hind limb were limited and probably do not allow to metriorhynchids to move in land (Herrera et al., 2014a). According to the body length estimation (2.6 m) Cricosaurus araucanensis is the smallest metriorhynchid found in the Neuquén Basin, similar in body length to Cricosaurus vignaudi (Frey, Buchy, Stinnesbeck, and LópezOliva, 2002) and larger than Cricosaurus elegans (Wagner, 1852) (1.4 m) (Herrera, 2012).

The first description of a metriorhynchid natural endocast corresponds to the description of the nasal salt gland of Cricosaurus araucanensis made by Fernández and Gasparini (2000). In 2008, Fernández and Gasparini proposed that the hypertrophied salt gland of $C$. araucanensis had a high excretory capability and that $C$. araucanensis represents an advanced stage of the basic physiological model to marine adaptations in reptiles. Fernández and Herrera (2009) described the natural snout endocasts and proposed that the modifications of the paranasal sinus system were associated with the internalization of the antorbital cavity and the development of a neomorphic opening for salt glands drainage (i.e., preorbital opening and fossa). The more recent study of the natural snout endocasts includes the construction of a digital cast based on CT scan of the holotype (Herrera et al., 2013a). This study indicates that the skeletal changes of metriorhynchids were coupled with changes in the soft anatomy of cephalic structures. The comparison between the natural and digital cast showed that both data are congruent, and they can be combined to generate an 
accurate reconstruction, which improves our knowledge of the preorbital anatomy of metriorhynchids. Based on this study the authors proposed that the nasal salt glands were structures highly vascularised, and the reduction of the olfactory bulbs and tract indicates that the aerial olfaction
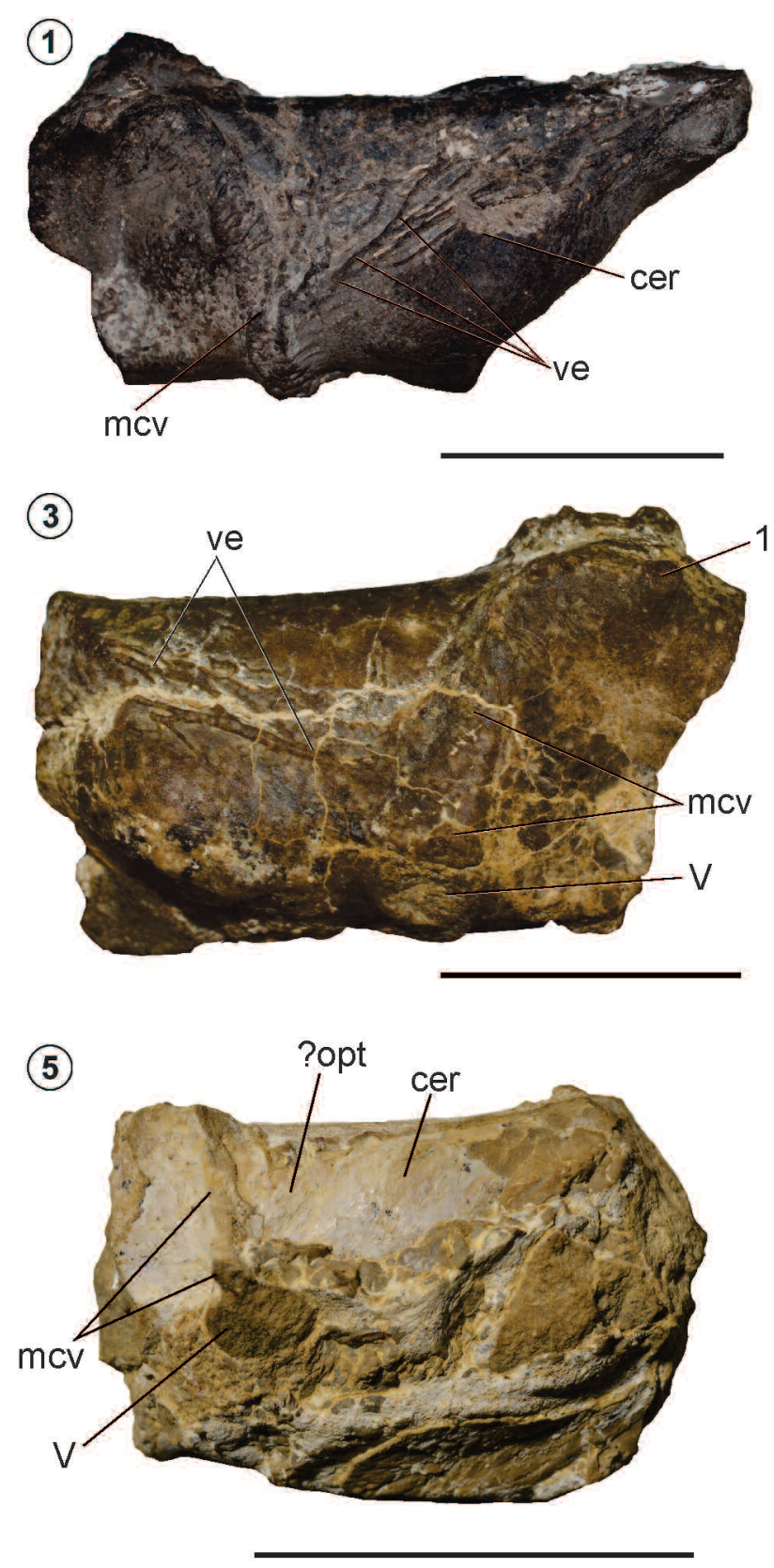

was not well developed in this group.

A significant number of well-preserved natural casts of the brain of Cricosaurus araucanensis (Fig. 2) were recently exhumed in Tithonian levels of the Vaca Muerta Formation, in the Pampa Tril area (Herrera et al., 2014b). Only in the
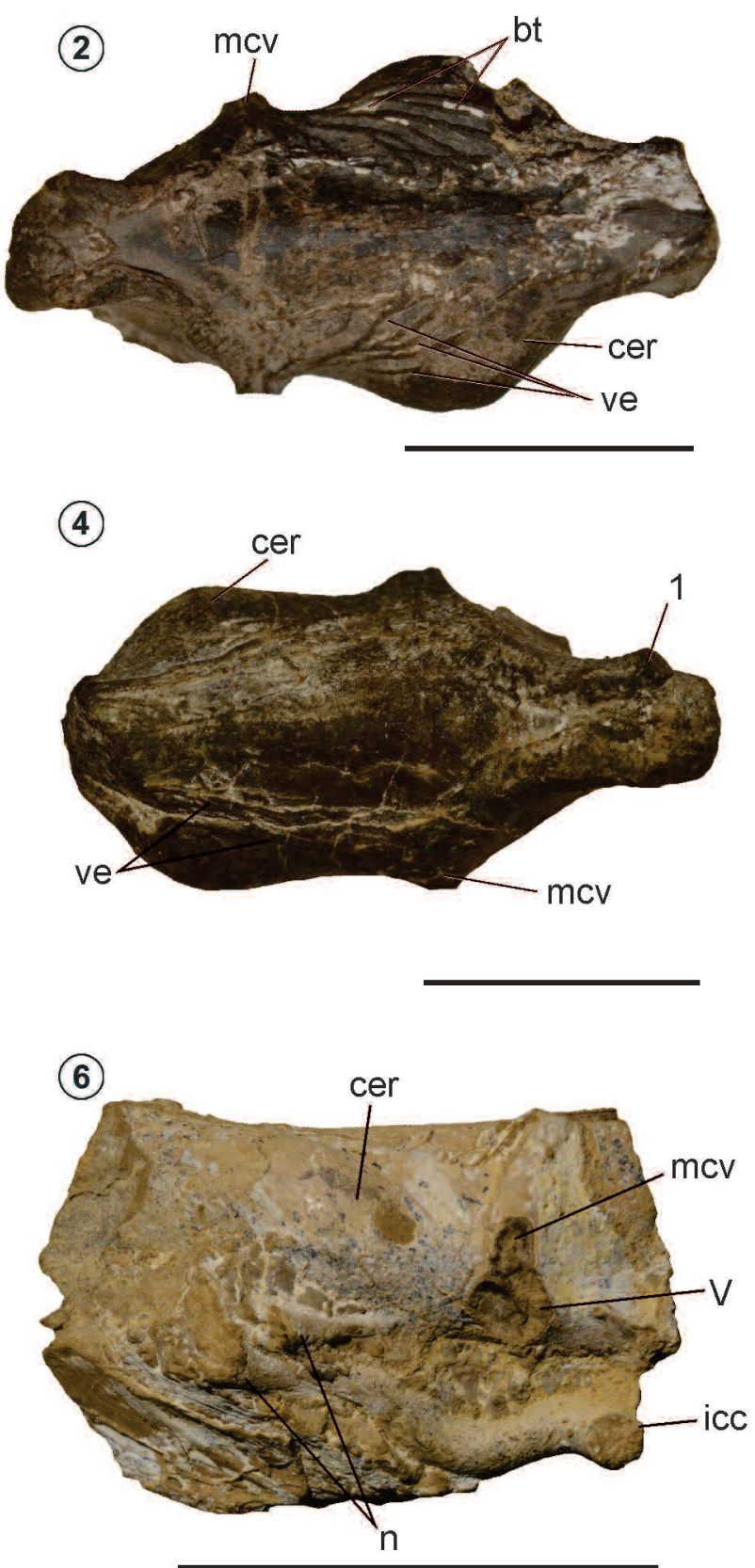

Figure 2. Cricosaurus araucanensis natural brain endocast. 1-2, MOZ-PV 7201; 1, right lateral view; 2, dorsal view; 3-4, M0Z-PV 7261; 3, left lateral view; 4, dorsal view; 5-6, MLP 73-II-27-3; 5, right lateral view; 6, left lateral view. Scale bars= 1-4, 25 mm; 5-6, $100 \mathrm{~mm}$. Abbreviations: bt, bone tissue; cer, cerebral hemisphere; icc, internal carotid canal; mcv, middle cerebral vein; $n$, cranial nerves canals; ?opt, optic lobe; ve, vessel; 1, tube-like cavity; $\mathbf{V}$, cranial nerve foramen and/or canal. 
specimen MLP 76-XI-19-1 the endocast is completely preserved, from the olfactory bulbs to the medulla oblongata, but is it not completely exposed (Fig. 1.6, 8). In most of the specimens the olfactory tract and bulbs are not preserved. The endocasts are elongated and the angles formed by the hindbrain, midbrain and forebrain are not developed, and the cerebral hemisphere are laterally extended (Figs. 1.6, 2). Conspicuous blood vessel fillings cover almost all the dorsal surface of the cerebral hemispheres (Fig. 2.1-4). In some specimens, between these blood vessel fillings, there is bone tissue preserved (Fig. 2.2). In the lateral view of the endocasts there is a bilobate filling with the posterodorsal lobule much smaller than the anteroventral one. The small lobule corresponds to the middle cerebral vein and the large to the trigeminal nerve/ganglion (Fig. 2.). In MOZ PV 7201 (Fig. 2.2) the blood vessel fillings that cover the cerebral hemispheres are connected to the middle cerebral vein. In MLP 73-II-27-3, between the cerebral hemispheres and the middle cerebral vein, a small protuberance is recognized. This structure would correspond to the optic lobe (Fig. 2.5). In MLP 73-II-27-3 conspicuous filling of cranial nerves are preserved (Fig. 2.6). The proximal portion of cavity 1 of Fernández et al. (2011), cavity that connects the dorsal longitudinal venous sinus with the cranio-quadrate foramen, was identified in both sides of MOZ-PV 7261 (Fig. 2.3-4), and in the digital cast of the holotype of Cricosaurus araucanensis (Herrera et al., in progress). In MOZ-PV 7261 the proximal portion of the cavity 1 is preserved as a protuberance in the dorsoposterior region of the brain (Fig. 2.3-4).

Cricosaurus lithographicus Herrera, Gasparini and Fernández, 2013

Figure 3

Holotype. MOZ-PV 5787, complete skull with articulated lower jaws, postcranium composed by cervical, dorsal, sacral and caudal vertebrae, an isolated pectoral girdle element, incomplete forelimb and hind limb, pelvic girdle elements.

Figure 3. Cricosaurus lithographicus, MOZ-PV 5787. 1, skull in dorsal view; $2-3$, posterior dentary tooth; 2 , carina in distal view; 3 , carina in mesial view; 4, postcranial elements. Scale bars $=1,4,100 \mathrm{~mm} ; 2-$ $3,1 \mathrm{~mm}$.

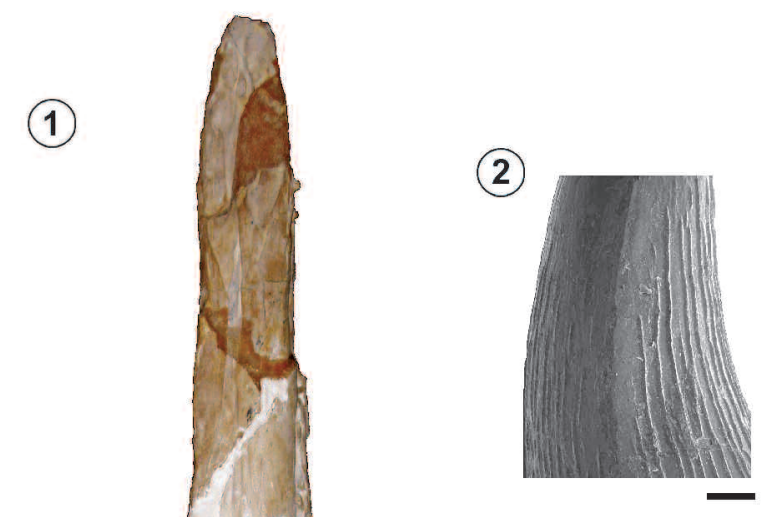

(4)

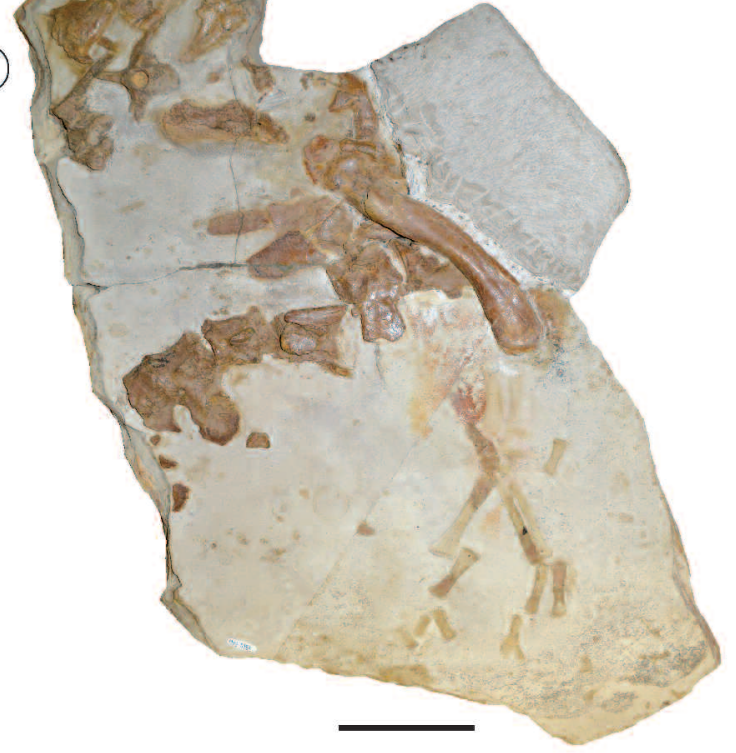


Ocurrence. Upper lower-middle upper Tithonian levels of El Ministerio quarry, Los Catutos Member (Neuquén Province). Comments. Cricosaurus lithographicus was the second species of Cricosaurus described for the Neuquén Basin. The material designated as Cricosaurus lithographicus by Herrera et al. (2013c) had previously been briefly mentioned and illustrated (e.g., Gasparini et al., 1995; Gasparini and Fernández, $2005,2011)$. This species, with a body length of approximately 3.36 m (Herrera, 2012), is the largest Rhacheosaurini from the Vaca Muerta Formation. The main difference between C. lithographicus and C. araucanensis lies in the dentition. Both species have bicarinated teeth with a smooth carina on the mesial and distal margin. In C. lithographicus, the number of maxillary teeth is fewer and the interalveolar spaces are larger than in C. araucanensis. Also, in the former taxon, the teeth have conspicuous, but not continuous, longitudinal ridges that run along the crown, except in the apical region that is smooth (Fig. 3.2-3), whereas in C. araucanensis the teeth have fine longitudinal ridges (Fig. 1.2) only visible under high magnification (e.g., SEM analysis).

Herrera et al. (2013c) found C. lithographicus nested with Cricosaurus macrospondylus (Koken, 1883) and Cricosaurus araucanensis in a polytomy. More recently, Cricosaurus lithographicus was found as the sister taxon of C. macrospondylus, with Cricosaurus araucanensis as the sister taxa of this clade (Herrera et al., 2015).

Subfamily GeOSAURINAE Lydekker, 1889 (sensu Young and Andrade, 2009)

Tribe GeOSAuRINI Lydekker, 1889 (sensu Cau and Fanti, 2011)

Genus Dakosaurus Quenstedt, 1856

Type species. Geosaurus maximus Plieninger, 1846. Upper Kimmeridgian, Staufenbei Giengen, Baden-Württemberg, Germany.

Dakosaurus andiniensis Vignaud and Gasparini, 1996 Figure 4.1

Holotype. MHNSR PV 344, an isolated rostrum slightly eroded.

Referred material. MOZ-PV 026, anterior region of the snout and preorbital natural endocast; MOZ-PV 6140, anterior mandibular fragment; MOZ-PV 6146, skull with articulated lower jaws and fragmentary postcranial remains.

Ocurrence. The holotype was found in Tithonian-Berriasian levels of the Catan Lil, Barranca River (Malargüe, Mendoza Province). Specimen MOZ-PV 026 was found in Tithonian levels of Mallín Quemado area (Neuquén Province), MOZPV 6140 and MOZ-PV 6146 were found in Yesera del Tromen-Pampa Tril area (Neuquén Province), in Berriasian and Tithonian levels respectively.

Comments. In 2009, Pol and Gasparini made a comprehensive description of the an almost complete and three dimensionally preserved skull and lower jaws of Dakosaurus andiniensis (MOZ-PV 6146), which is characterized by a short and high snout with ziphodont dentition. Phylogenetic analyses showed that Dakosaurus andiniensis is the sister taxon of D. maximus, a form of the Jurassic of Europe (Pol and Gasparini, 2009; Young et al., 2012; Herrera et al., 2015; Wilberg, 2015). Based on skull length of MOZ-PV 6146, the body length estimation is $4.20 \mathrm{~m}$ (Herrera, 2012). In 2010, in the Mallín Quemado area, one skull of $D$. andiniensis that includes the natural endocasts of the snout was found (Fernández et al., 2010, 2012). The natural endocast reveals the presence of enlarged salt gland, the internalization of the antorbital cavity, and probably the presence of the suborbital diverticula (Fernández et al., 2012), however deeper studies are necessary and are being performed by Fernández et al. Also, in the same level, was found a quite articulated hind limb, probably referable to the same taxon (Fernández et al., 2012).

\section{Dakosaurus cf. D. andiniensis}

Figure 4.2-4

Referred material. MOZ-PV 089, skull incompletely preserved that includes the orbital and post-orbital regions as well as the exposed natural endocast of the brain cavity.

Ocurrence. Vega de Escalone locality (Neuquén Province) in the uppermost Tithonian levels (Substeueroceras koeneni Biozone-uppermost Tithonian to lowermost Berriasian).

Comments. Based on the absent of diagnostic features, a more accurate determination could not be done (Herrera and Vennari, 2015). However, its description constituted the first detailed report of the brain endocast morphology and cranial nerves of a metriorhynchid. 
The endocast has an anteroposteriorly elongated cerebral hemispheres and conspicuous blood vessel fillings covering almost all the dorsal surface of the hemispheres (Fig. 4.3). The bone tissue preserved between the blood vessel fillings, suggested that the dural envelope of this region was thin and that the cerebral hemispheres filled most of the cavity (Herrera and Vennari, 2015). The infilling of the cranial nerves III, IV and VI were identified (Fig. 4.3). One of them (CN III) is markedly enlarged (in diameter and com- pared with Gavialis gangeticus) and, based on this, was proposed that the eyeball of metriorhynchids might have had a great mobility and a great visual range (Herrera and Vennari, 2015). On the other hand, the distal portion of cavity 1 , and an enlarged internal carotid canal were recognized in the natural endocast (Fig. 4.3-4). These structures were previously identified in a digital cast of the Chilean metriorhynchid 'Metriorhynchus' cf. ' $M$ '. westermanni by Fernández et al. (2011).

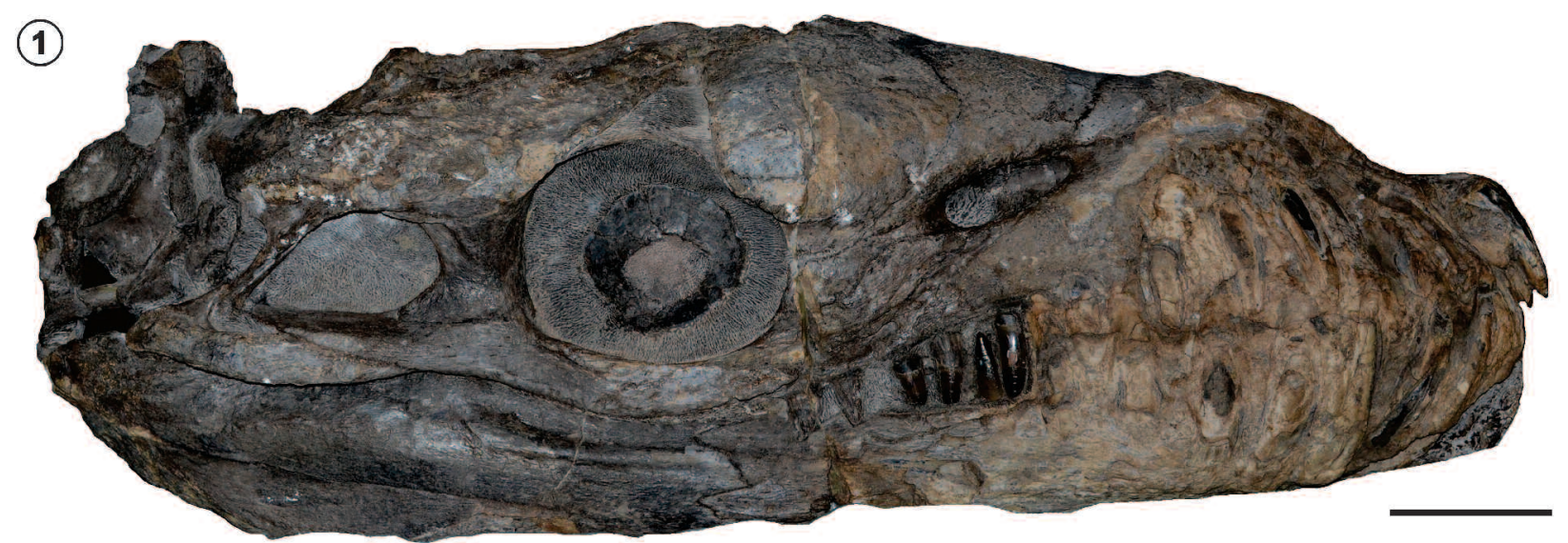

(2)
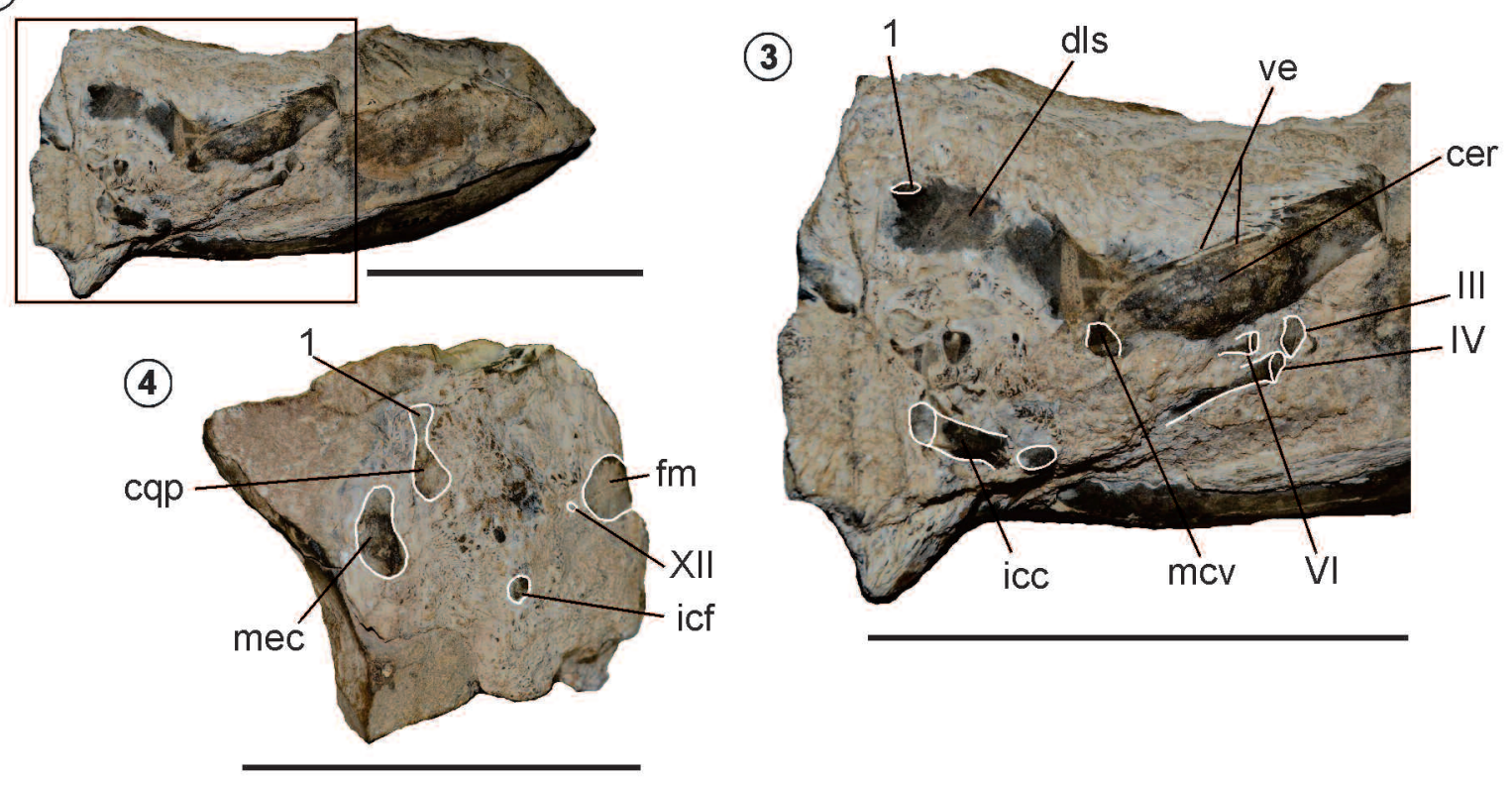

Figure 4. 1, Dakosaurus andiniensis, MOZ-PV 6146, skull in right lateral view; 2-4, Dakosaurus cf. D. andiniensis, M0Z-PV 089; 2, right lateral view showing the region of interest; 3 , detail of endocast; 4 , left latero-occipital view. Scale bars= $100 \mathrm{~mm}$. Abbreviations: cer, cerebral hemisphere; cqp, cranioquadrate passage; dls, dorsal longitudinal sinus; fm, foramen magnum; icc, internal carotid canal; icf, internal carotid foramen; mec, middle ear cavity; mcv, middle cerebral vein; ve, vessel; 1, tube-like cavity; III, IV, VI, XII, cranial nerves foramen and/or canals. 
Genus Purranisaurus Rusconi, 1948a

Figure 5

Type species. Purranisaurus potens Rusconi, 1948a. Arroyo del Cajón Grande, southwest of Malargüe Department, Mendoza Province. Upper Tithonian-lower Berriasian of Vaca Muerta Formation (biozone of Substeueroceras koeneni, Vennari et al., 2014).

Holotype. MJCM PV 2060, skull incompletely preserved without the most anterior portion; incomplete left lower jaw.

Comments. This taxon corresponds to the first metriorhynchid skull described in Argentina, although it was originally described as a plesiosaur (Rusconi, 1948a,b) and then reassigned to Nothosauria (Rusconi, 1967). Years later, some authors placed Purranisaurus potens in 'Crocodylia' or 'Metriorhynchidae?' (e.g., Romer, 1956; Kuhn, 1968; Gasparini, 1973a). During decades the systematic status of $P$. potens has been debated (see Gasparini, 1973a, 1985; Buffetaut, 1982; Vignaud, 1995; Pol and Gasparini, 2007; Young et al., 2010; among others) but the poor preparation of this specimen precluded its determination. A recent preparation of the material allowed its redescription as well as the exploration of its phylogenetic relationships (see Herrera et al., 2015). Hitherto Purranisaurus is a monotypic genus for South America, and P. potens is the second Geosaurini genus described for Argentina. The skull is incompletely preserved, thus an estimation of body length can not be made.

\section{DISCUSSION}

The Upper Jurassic and Lower Cretaceous fossil record of Patagonian metriorhynchids is outstanding, both in quantity and quality, although taxonomical diversity is lower than that of the reported for the Tethys. In the South American margins of the Eastern Pacific no metriorhynchid have been collected from Oxfordian and Kimmeridgian levels, while in the Tethys and Hispanic Corridor (Mexico and Cuba) several taxa have been found (e.g., Gasparini and IturraldeVinent, 2001; Buchy et al., 2007; Buchy, 2008; Young et al., 2012, 2013). In Patagonia, Oxfordian-Early Kimmeridgian marine levels are restricted to marine platform limestones (La Manga Formation) and evaporites (Auquilco Formation) without evidences of vertebrates, whereas the Kimmerid-
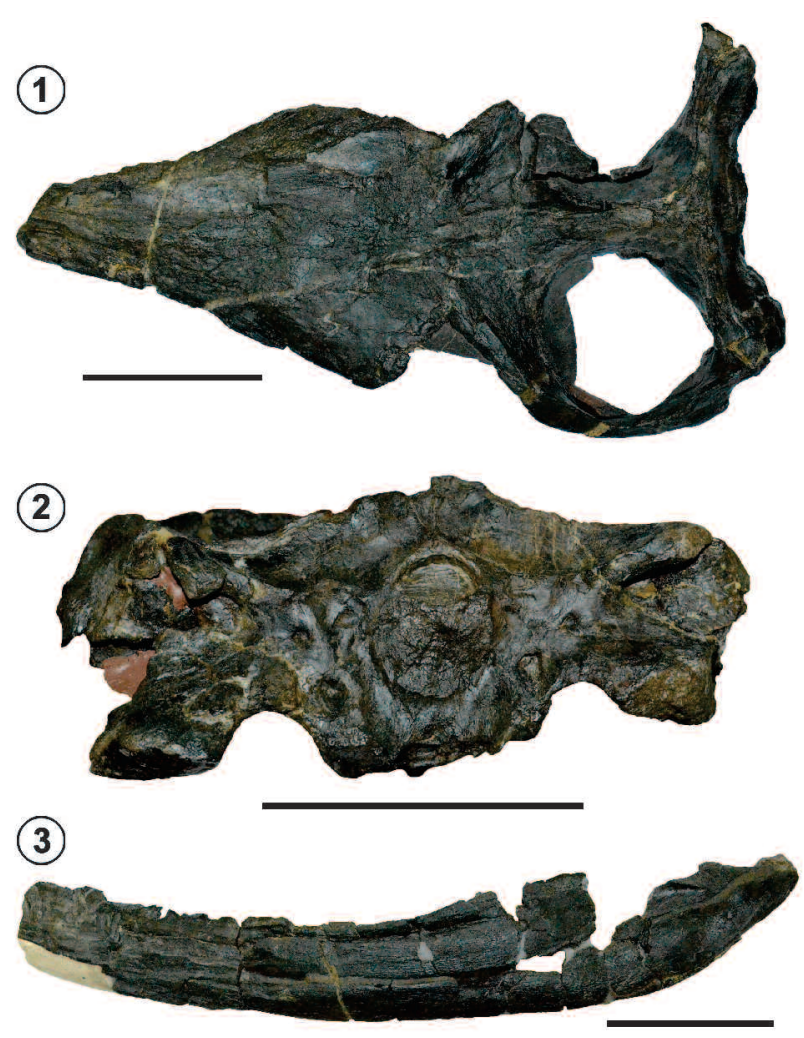

Figure 5. Purranisaurus potens, MJCM PV 2060. 1, skull in dorsal view; 2 , skull in occipital view; $\mathbf{3}$, left mandibular ramus in lateral view. Scale bars $=100 \mathrm{~mm}$.

gian is represented by continental (Tordillo Formation) and volcanics (Río Damas Formation) deposits (A.C. Garrido, pers. comm.). During the Tithonian-Berriasian the diversity of Patagonia metriorhynchids is also lower than in the Tethys however, this could be due to uneven collecting efforts. The major taxonomic diversity of Patagonian metriorhynchids have been collected in upper Tithonianlower Berriasian levels of the Vaca Muerta Formation, and includes at least three different taxa: Dakosaurus andiniensis, Cricosaurus araucanensis and Purranisaurus potens. Dakosaurus sp. and Cricosaurus sp. have also been recorded in the Hispanic Corridor. Based on the exhaustive systematic revisions performed by Young and Andrade (2009) and Young et al. (2012) and what we know so far, both western Tethys and Eastern Pacific probably had endemics genera for the Tithonian-Berriasian such as: Plesiosuchus, Geosaurus, Rhacheosaurus (for the western Tethys), and Purranisaurus for Patagonia. No endemic genera of metriorhynchids are recognized for the Hispanic Corridor. 
Some undescribed Patagonian specimens need to be described. These new materials, as well as paleontological prospections of poorly sampled areas of Patagonia, will help to test whether the differences in the evolutionary scenarios between the western Tethys and Eastern Pacific faunas are due to uneven fossil sampling or not.

\section{Natural casts of the brain}

The information on natural and/or artificial brain casts of thalattosuchians in general, and metriorhynchids in particular, is scarce. In this way, the description of the Geosaurini brain endocast of Dakosaurus cf. D. andiniensis improved the scarce knowledge of the neuroanatomy of metriorhynchids.

Based on the available information, in Cricosaurus araucanenis, Dakosaurus cf. D. andiniensis, as well as in a teleosaurid (Seeley, 1880), Steneosaurus pictaviensis (Wharton, 2000), and 'Metriorhynchus' cf. ' $M$ '. westermanni (Fernández et al., 2011) the angles formed by the hindbrain, midbrain and forebrain are much less developed than in extant crocodiles (e.g., Caiman crocodylus, Hopson, 1979: fig. 1B; Crocodylus johnstoni, Witmer et al., 2008: fig. 6.3A; Caiman yacare, Bona and Paulina Carabajal, 2013: fig. 6B) and less developed than in some extinct crocodyliforms (e.g., Pholidosaurus meyeri, Hopson, 1979: fig. 10; Caiman gasparinae, Bona and Paulina Carabajal, 2013: fig. 6A). In the mosasaur Platecarpus (Hopson, 1979: fig. 8) and in an ichthyosaur (Marek et al., 2015: fig. 11A-B) the brain casts seems to be much flexed than in metriorhynchids. In comparison with other marine reptiles, metriorhynchids brain endocast are elongated, as in nothosaurs, plesiosaurs and ichthyosaurus, and the cerebral hemispheres are somewhat enlarged as in an ichthyosaur (Marek et al., 2015). If the identification of the optic lobe in Cricosaurus araucanensis is correct, this structure is small in comparison with that of ichthyosaurs (Marek et al., 2015: fig. 10). Seeley (1880) described a deep excavation in the posterodorsal region of the braincase of a teleosaurid, and he interpreted this cavitity as for the optic lobe. However, this cavity probably corresponds to a part of the cavity 1 or a part of a venous sinus, and not to the cavity for the optic lobe. As in Cricosaurus araucanensis, in Steneosaurus pictaviensis the optic lobe appears to be small (Wharton, 2000: fig. 1a).
Based on the current knowledge, metriorhynchids endocasts ('Metriorhynchus'cf. 'M'. westermanni, Dakosaurus cf. D. andiniensis, and Cricosaurus araucanensis) share the following features: conspicuous blood vessel fillings that cover almost all the dorsal surface of the cerebral hemispheres, an enlarged internal carotid canal, conspicuous filling of cranial nerves III, IV and XI, and the cavity that connects the dorsal longitudinal venous sinus with the cranio-quadrate foramen. However, fine details (as the blood vessel fillings and nerves) are only recognized in the endocasts, a similar situation was described for the natural and digital cast of the preorbital region of Cricosaurus araucanensis (Herrera et al., 2013a). The presence of the same endocasts features in Geosaurini and Rhacheosaurini tribes suggests that they were widely distributed within metriorhynchids, and that could be related with adaptations to a pelagic lifestyle.

A more exhaustive analysis of the metriorhynchid endocasts (natural and digital) is fundamental to determine if the identification of the optic lobe is correct, as well as to understand the biological/functional significance of the poor developed flexures in the brain of metriorhynchids, and the brain vascular system, among other features. Improving the knowledge of these topics is essential to understand the secondary adaptation of the metriorhynchids to the pelagic environment, adaptation unique among Archosauria.

\section{Future perspectives of the study of Patagonian metriorhynchids}

The most remarkable peculiarities of the Patagonian metriorhynchid fossil records are the excellent preservation of their skeletons (in most cases the specimens are tridimensionally preserved) and the preservation of the natural endocasts of the skull cavities. These oustanding fossil records would allow us to continue exploring interesting paleobiological aspects such as the analyse of sensory capabilities (vision, olfaction and hearing) and their relationships with physiological and behavioural attributes. The current evidence suggests that the soft anatomy of the brain in metriorhynchids seems to be as modified and could be coupled with skeletal changes (as the soft anatomy of the snout, and the postcranium), in relation of their pelagic lifestyle. Ongoing contributions will allow determining detailed information regarding these modifications and their 
significance in the secondary adaptation of metriorhynchids to the pelagic environment.

\section{ACKNOWLEDGMENTS}

I thank A. Garrido (MOZ) for his rewarding support in the fieldtrips and the accurate stratigraphic information of the material. A. Garrido and B. Bollini (MOZ) for access to fossil material. I would also like to thank M.S. Fernández (MLP) for its comments and helpful discussions on a draft of this paper and Natalia Magnani who revised the English grammar. Comments from D. Pol and M. Young greatly improved the manuscript. My special thanks go to Zulma Gasparini for her continuous support, affection, and generosity. She has accompanied my work with invaluable advices based on her comprehensive knowledge. This research has been partially supported by the Agencia Nacional de Promoción Científica y Tecnológica (PICTs 2012-0748, 2013-0618), CONICET (PIP 0433), and Programa de Incentivos N749/14, UNLP, Argentina.

\section{REFERENCES}

Andrews, C.W. 1913. A descriptive catalogue of the marine reptiles of the Oxford Clay. Part II. British Museum (Natural History), London, $206 \mathrm{p}$.

Bona, P., and Paulina Carabajal, A. 2013. Caiman gasparinae sp. nov., a huge alligatorid (Caimaninae) from the late Miocene of Paraná, Argentina. Alcheringa: An Australasian Journal of Palaeontology 37: 462-473.

Buchy, M.-C. 2008. New occurrence of the genus Dakosaurus (Reptilia, Thalattosuchia) in the Upper Jurassic of north-eastern Mexico, with comments upon skull architecture of Dakosaurus and Geosaurus. Neues Jahrbuch für Geologie und Paläontologie Abhandlungen 249: 1-8.

Buchy, M.-C., Stinnesbeck, W., Frey, E., and Gonzalez, A.H. 2007. Première mention du genre Dakosaurus (Crocodyliformes, Thalattosuchia) dans le Jurassique supérieur du Mexique. Bulletin Société Géologique de France 178: 63-69.

Buffetaut, E. 1982. Radiation évolutive, paléoécologie et biogéographie des crocodiliens mésosuchiens. Mémoires de la Société Géologique de France 60: 1-88.

Cau, A., and Fanti, F. 2011. The oldest known metriorhynchid crocodylian from the Middle Jurassic of North-eastern Italy: Neptunidraco ammoniticus gen. et sp. nov. Gondwana Research 19: 550-565.

Fernández, M., and Gasparini, Z. 2000. Salt glands in a Tithonian metriorhynchid crocodyliform and their physiological significance. Lethaia 33: 269-276.

Fernández, M., and Gasparini, Z. 2008. Salt glands in the Jurassic metriorhynchid Geosaurus: implications for the evolution of osmoregulation in Mesozoic marine crocodyliforms. Naturwissenschaften 95: 79-84.

Fernández, M.S., and Herrera, Y. 2009. Paranasal sinus system of Geosaurus araucanensis and the homology of the antorbital fenestra of metriorhynchids (Thalattosuchia: Crocodylomorpha). Journal of Vertebrate Paleontology 29: 702-714.

Fernández, M.S., Gasparini, Z., and Herrera, Y. 2010. Tithonian marine herpetofaunas from the Neuquén Basin (Northwest Patagonia, Argentina). International Symposium on Triassic and later Marine Vertebrate Faunas (Beijing), Program and Abstract: 22-30.

Fernández, M.S., Carabajal, A.P., Gasparini, Z., and Chong Díaz, G. 2011. A metriorhynchid crocodyliform braincase from northern
Chile. Journal of Vertebrate Paleontology 31: 369-377.

Fernández, M.S., Garrido, A., Hiriart, L., Herrera, Y., and Talevi, M. 2012. Reptiles marinos titonianos (Jurásico Superior) recuperados en Mallín Quemado (Fm. Vaca Muerta, área Sierra de la Vaca Muerta, Neuquén, Argentina). Ameghiniana, Suplemento Resúmenes 49: R28.

Fitzinger, L.J.F.J. 1843. Systema Reptilium. Braumüller et Seidel, Wien, $106 \mathrm{p}$.

Fraas, E. 1901. Die Meerkrokodile (Thalattosuchia n.g.), eine Sauriergruppe der Juraformation. Jahreshefte des Vereins für vaterländische Naturkunde Württembergs 57: 409-418.

Fraas, E. 1902. Die Meer-Krocodilier (Thalattosuchia) des Oberen Jura unter specieller Berücksichtigung von Dacosaurus und Geosaurus. Palaeontographica 49: 1-79.

Frey, E., Buchy, M.-C., Stinnesbeck, W., and López-Oliva, J.G. 2002. Geosaurus vignaudin. sp. (Crocodyliformes: Thalattosuchia), first evidence of metriorhynchid crocodilians in the Late Jurassic (Tithonian) of central-east Mexico (State of Puebla). Canadian Journal of Earth Sciences 39: 1467-1483.

Gasparini, Z. 1973a. Revisión de "? Purranisaurus potens" Rusconi, 1948 (Crocodilia, Thalattosuchia). Los Thalattosuchia como un nuevo Infraorden de los Crocodilia. V Congreso Geológico Argentino (Villa Carlos Paz), Actas 3: 423-431.

Gasparini, Z. 1973b. [Revisión de los Crocodilia (Reptilia) fósiles del Territorio Argentino: su evolución, sus relaciones filogenéticas, su clasificación y sus implicancias estratigráficas. Tesis Doctoral, Facultad de Ciencias Naturales y Museo, Universidad Nacional de La Plata, La Plata, 169 p. Unpublished.].

Gasparini, Z. 1985. Los reptiles marinos jurásicos de América del Sur. Ameghiniana 22: 23-34.

Gasparini, Z., and Dellapé, D. 1976. Un nuevo cocodrilo marino (Thalattosuchia, Metriorhynchidae) de la Formación Vaca Muerta (Tithoniano) de la Provincia de Neuquén (Argentina). $1^{\circ}$ Congreso Geológico Chileno (Santiago de Chile), Actas: C1-C21.

Gasparini, Z., and Chong Díaz, G. 1977. Metriorhynchus casamiquelai n. sp. (Crocodilia, Thalattosuchia) a marine crocodile from the Jurassic (Callovian) of Chile, South America. Neues Jahrbuch für Geologie und Paläontologie, Abhandlungen 153: 341-360.

Gasparini, Z., de la Fuente, M., and Fernández, M. 1995. Sea reptiles from the lithographic limestones of the Neuquén Basin, Argentina. II International Symposium on Lithographic Limestones (Madrid), Extended Abstracts: 81-84.

Gasparini, Z.B., and Iturralde-Vinent, M. 2001. Metriorhynchid crocodiles (Crocodyliformes) from the Oxfordian of Western Cuba. Neues Jahrbuch für Geologie und Paläontologie Monatshefte 9: 534-542.

Gasparini, Z., and Fernández, M. 2005. Jurassic marine reptiles of the Neuquén Basin: records, faunas and their palaeobiogeographic significance. In: G.D. Veiga, L.A. Spalletti, J.A. Howell, and E. Schwarz (Eds.), The Neuquén Basin, Argentina: a case study in sequence stratigraphy and basin dynamics. Geological Society, London, Special Publications 252, p. 279-294.

Gasparini, Z., and Fernández, M.S. 2011. Reptiles marinos mesozoicos. In: H.A. Leanza, C. Arregui, O. Carbone, J.C. Daniela, and J.M. Vallés (Eds.), Relatorio del XVIII Congreso Geológico Argentino. Asociación Geológica Argentina, Buenos Aires, p. 529-538.

Gasparini, Z.B., Vignaud, P., and Chong, G. 2000. The Jurassic Thalattosuchia (Crocodyliformes) of Chile: a paleobiogeographic approach. Bulletin de la Société Géologique de France 171: 657-664.

Gasparini, Z., Cichowolski, M., and Lazo, D. 2005. First record of Metriorhynchus (Reptilia: Crocodyliformes) in the Bathonian 
(Middle Jurassic) of the Eastern Pacific. Journal of Paleontology 79: 805-809.

Herrera, Y. 2012. [Análisis morfológico y paleobiológico de Cricosaurus araucanensis (Gasparini y Dellapé, 1976) (Crocodyliformes: Metriorhynchidae). Tesis Doctoral, Facultad de Ciencias Naturales y Museo, Universidad Nacional de La Plata, La Plata, Vol. 1: p. 346; Vol. 2: p. 116. Unpublished.].

Herrera, Y., and Vennari, V.V. 2015. Cranial anatomy and neuroanatomical features of a new specimen of Geosaurini (Crocodylomorpha: Metriorhynchidae) from west-central Argentina. Historical Biology 27: 33-41.

Herrera, Y., Fernández, M.S., and Varela, J.A. 2009. Morfología del miembro anterior de Geosaurus araucanensis Gasparini y DeIlapé, 1976 (Crocodyliformes: Thalattosuchia). Ameghiniana 46: 657-667.

Herrera, Y., Fernández, M.S., and Gasparini, Z. 2013a. The snout of Cricosaurus araucanensis: a case study in novel anatomy of the nasal region of metriorhynchids. Lethaia 46: 331-340.

Herrera, Y., Fernández, M.S., and Gasparini, Z. 2013b. Postcranial skeleton of Cricosaurus araucanensis (Crocodyliformes: Thalattosuchia): morphology and palaeobiological insights. Alcheringa: An Australasian Journal of Palaeontology 37: 285-298.

Herrera, Y., Gasparini, Z., and Fernández, M.S. 2013c. A new Patagonian species of Cricosaurus (Crocodyliformes, Thalattosuchia): first evidence of Cricosaurus in Middle-Upper Tithonian lithographic limestones from Gondwana. Palaeontology 56: 663-678.

Herrera, Y., Gasparini, Z., and Fernández, M.S. 2015. Purranisaurus potens Rusconi, an enigmatic metriorhynchid from the Late Jurassic-Early Cretaceous of the Neuquén Basin. Journal of Vertebrate Paleontology 35: e904790. DOI: 10.1080/ 02724634.2014.904790

Herrera, Y., Fernández, M.S., Gasparini, Z., and Campos, L. 2014a. Morphology of the sacral region of Cricosaurus araucanensis (Crocodylomorpha: Thalattosuchia): insights into metriorhynchids reproductive strategies. 4th International Palaeontological Congress (Mendoza), Abstract Volume: 37.

Herrera, Y., Fernández, M.S., and Gasparini, Z. 2014b. Moldes naturales de la cavidad encefálica de los metriorrínquidos: resultados preliminares. Ameghiniana, Suplemento Resúmenes 51: 13R-14R.

Hopson, J.A. 1979. Paleoneurology. In: C. Gans (Ed.), Biology of the Reptilia, Volume 9. Academic Press, London, p. 39-146.

Hua, S., and de Buffrénil, V. 1996. Bone histology as a clue in the interpretation of functional adaptations in the Thalattosuchia (Reptilia, Crocodylia). Journal of Vertebrate Paleontology 16: 703-717.

Koken, E. 1883. Die reptilian der norddeutschen unteren Kreide. Zeitschrift deutschen Geologischen Gesellschaft 35: 735-827.

Kuhn, O. 1968. Die Vortzeitlichen Krokodile. Verlag Oeben Krailing, München, $124 \mathrm{p}$.

Lydekker, R. 1889. On the remains and affinities of five genera of Mesozoic reptiles. The Quarterly Journal of the Geological Society of London 45: 41-59.

Marek, R.D., Moon, B.C., Williams, M., and Benton, M.J. 2015. The skull and endocranium of a Lower Jurassic ichthyosaur based on digital reconstructions. Palaeontology 58: 723-742.

Plieninger, T. 1846. Prof. Dr. Th. Plieninger hielt nachstehenden Vortrag über ein neues Sauriergenus und die Einreihung der Saurier mit flachen, schneidenden Zähnen in Eine Familie. Württembergische naturwissenschaftliche Jahreshefte 2: 148-154.

Pol, D., and Gasparini, Z. 2007. Crocodyliformes. In: Z. Gasparini, L. Salgado, and R. Coria (Eds.), Patagonian Mesozoic Reptiles. In- diana University Press, Indiana, p. 116-142.

Pol, D., and Gasparini, Z. 2009. Skull anatomy of Dakosaurus andiniensis (Thalattosuchia: Crocodylomorpha) and the phylogenetic position of Thalattosuchia. Journal of Systematic Palaeontology 7: 163-197.

Quenstedt, F.A. 1856. Der Jura. Laupp, Tübingen, 842 p.

Romer, A.S. 1956. Osteology of the reptiles. University of Chicago Press, Chicago, $772 \mathrm{p}$.

Rusconi, C. 1948a. Nuevo plesiosaurio, pez y langosta de mar jurásico de Mendoza. Revista del Museo de Historia Natural de Mendoza 2: 3-12.

Rusconi, C. 1948b. Plesiosaurios del Jurásico de Mendoza. Anales de la Sociedad Cientifica Argentina 146: 327-351.

Rusconi, C. 1967. Animales extinguidos de Mendoza y de la Argentina. Edición Oficial, Mendoza, 489 p.

Seeley, H.G. 1880. Note on the cranial characters of a large teleosaur from the Whitby Lias preserved in the Woodwardian museum of the University of Cambridge, indicating a new species, Teleosaurus eucephalus. Quarterly Journal of the Geological Society 36: 627-634.

Vennari, V.V., Lescano, M., Naipauer, M., Aguirre-Urreta, B., Concheyro, A., Schaltegger, U., Armstrong, R., Pimentel, M., and Ramos, V.A. 2014. New constraints on the Jurassic-Cretaceous boundary in the High Andes using high-precision U-Pb data. Gondwana Research 26: 374-385.

Vignaud, P. 1995. [Les Thalattosuchia, crocodiles marins du Mesozoïque: systématique phylogénétique, paléoécologie, biochronologie et implications paléogéographiques. Ph.D. dissertation, Université de Poitiers, Poitiers, Francia, 265 p. Unpublished.].

Vignaud, P., and Gasparini, Z. 1996. New Dakosaurus (Crocodylomorpha, Thalattosuchia) from the Upper Jurassic of Argentina. Comptes Rendus de l'Académie des Sciences, Paris 2: 245-250.

Wagner, A. 1852. Neu-aufgefundene saurier-veberreste aus den lithographischer Schiefern ind den obern Juralke. Abhandlungen der Mathemat. Physikalischen Classe der Königlich Bayerischen Akademie der Wissenschaften 6: 661-710.

Wagner, A. 1858. Zur Kenntniss der Sauier aus den lithographischen Schiefen. Abhandlungen der Mathemat. Physikalischen Classe der Königlich Bayerischen Akademie der Wissenschaften 8: 415-528.

Walker, A.D. 1970. A revision of the Jurassic reptile Hallopus victor (Marsh), with remarks on the classification of crocodiles. Philosophical Transactions of the Royal Society London B 257: 323372.

Wharton, D.S. 2000. An enlarged endocranial venous system in Steneosaurus pictaviensis (Crocodylia: Thalattosuchia) from the Upper Jurassic of Les Lourdines, France. Comptes Rendus de I'Académie des Sciences 331: 221-226.

Wilberg, E.W. 2015. A new metriorhynchoid (Crocodylomorpha, Thalattosuchia) from the Middle Jurassic of Oregon and the evolutionary timing of marine adaptations in thalattosuchian crocodylomorphs. Journal of Vertebrate Paleontology 35: e902846. DOI: 10.1080/02724634.2014.902846.

Witmer, L.M., Ridgely, R.C., Dufeau, D.L., and Semones, M.C. 2008. Using CT to peer into the past: 3D visualization of the brain and ear regions of birds, crocodiles, and nonavian dinosaurs. In: $\mathrm{H}$. Endo, and R. Frey (Eds.), Anatomical Imaging: Towards a New Morphology. Springer-Verlag, Tokyo, p. 67-87.

Young, M.T., and Andrade, M.B. 2009. What is Geosaurus? Redescription of Geosaurus giganteus (Thalattosuchia: Metriorhynchidae) from the Upper Jurassic of Bayern, Germany. Zoological Journal of the Linnean Society 157: 551-585. 
Young, M.T., Bell, M.A., and Brusatte, S.L. 2011. Craniofacial form and function in Metriorhynchidae (Crocodylomorpha: Thalattosuchia): modelling phenotypic evolution with maximum likelihood methods. Biological Letters 7: 913-916.

Young, M.T., Brusatte, S.L., Ruta, M., and Andrade, M.B. 2010. The evolution of Metriorhynchoidea (Mesoeucrocodylia, Thalattosuchia): an integrated approach using geometric morphometrics, analysis of disparity and biomechanics. Zoological Journal of the Linnean Society 158: 801-859.

Young, M.T., Brusatte, S.L., de Andrade, M.B., Desojo, J.B., Beatty, B.L., Steel, L., Fernández, M.S., Sakamoto, M., Ruiz-Omenáca, J.I., and Schoch, R.R. 2012. The cranial osteology and feeding ecology of the metriorhynchid crocodylomorph genera Dakosaurus and Plesiosuchus from the Late Jurassic of Europe. PLOS ONE 7: e44985. DOI:10.1371/journal.pone.0044985.
Young, M.T., Andrade, M.B., Etches, S., and Beatty, B.L. 2013. A new metriorhynchid crocodylomorph from the Lower Kimmeridge Clay Formation (Late Jurassic) of England, with implications for the evolution of dermatocranium ornamentation in Geosaurini. Zoological Journal of the Linnean Society 169: 820-848.

Recibido: 9 de junio de 2015

Aceptado: 22 de septiembre de 2015 